\title{
Laborism. The Economics Driven by Labor
}

\author{
Mieczysław Dobija \\ Faculty Management, Cracow University of Economics, Cracow, Poland \\ Email: dobijam@uek.krakow.pl
}

Received 27 April 2015; accepted 19 May 2015; published 25 May 2015

Copyright (C) 2015 by author and Scientific Research Publishing Inc.

This work is licensed under the Creative Commons Attribution International License (CC BY).

http://creativecommons.org/licenses/by/4.0/

(c) (i) Open Access

\begin{abstract}
Economics includes many strands of thought such as Marxism and monetarism, but one thread, in which work is the essence and the most important part of the debate, manifested in the very beginning of civilization and continues to the present day. Laborism is a term used today in circles dealing with socio-economic thought. In this paper, however, a modern laborism is presented as a compact, coherent, integrated and scientific theory of economy, which is best for the practice of balanced socio-economic development. What's more, laborism has the potential to solve emerging problems. Principally, laborism involves all economic threads focused on expenditures of labor, including ancient labor economics and classical economics as well as the double-entry accounting theory. Contemporary laborism is reinforced by the scientific perception of labor and capital as well as positive results of research on the measurement of human capital and equitable remuneration. It is worth noting that contemporary laborism offers an economy with a low tax burden and no budget deficit.
\end{abstract}

\section{Keywords}

Labor, Laborism, Thermodynamics, Fair Compensations, Credit, Deflation

\section{Introduction}

The concept of laborism can be found in various dictionaries. The English Dictionary defines it as a political theory favoring the dominance of labor in the economic and political life of the country. The dictionary of Catholic social teaching describes the concept as the order elaborated in the economic model, which assumes that the work is not subject to capital or equivalent with respect to the capital. This means that capital is subordinated to work, and not vice versa, as was the case under the prevailing socio-economic regimes in capitalism and socialism. A satisfactory concept of laborism, however, has not yet been developed, even in terms of basic outlines that could be realized in different social systems and different countries.

These explanations characterize to some extent the concept of laborism, but both include a metaphor about subordination and exceeding. In this study, the author seeks a strictly scientific approach and formulations in 
order to develop a coherent theory of laborism anchored to the consistently defined categories. Laborism is derived from the word "labor". Work, as is commonly known, is the basic category of research, both in the physical and economic sciences. This premise suggests that the theory of laborism might be consistent with the model of the natural sciences.

Science is a means to create the knowledge needed to understand and control phenomena. The aim of this study is to present the scientific achievements that comprise laborism as a scientific, consistent and reliable theory indispensable in solving the problems of socio-economic development. This study begins with the ancient millennia, from the time when wisdom often prevailed over science. Then a labor economics was put in place that effectively assisted the management of town-states. Later considerations concerning the role of labor in classic economics and the views of its leader, Adam Smith, were subsequently considered the scientific foundations of laborism. The premise of laborism is a firm claim that the work is a solid scientific category recognized in thermodynamics and with full applications to economics.

In the second part of the study, considerations apply mostly to maintaining balance in the system of a money-goods economy. These analyses lead to original proposals. The basic premise is that the work of people is self-financing, since it is the transfer of human capital of employment to work objects. This understanding leads to the application of self-financing in the public sector, and thus elimination of the budget deficit, through the reform of the central bank. What's more, for sustainable economic development, it is necessary to introduce the family sector of the economy and the use of self-financing to pay mothers employed in this sector. It is an economic necessity (i.e., maintaining a balance between the stream of products value and the stream of money) not only for social or demographic reasons. In addition, the current problem of money emission and deflation is effectively solved.

Work, as explained by P. Atkins ([1]: 3-78), is an action against opposing forces (e.g., gravity, friction, resistance). The author points out, however, that even the work of electricity can be brought to interact with the force of gravity. If intellectual work requires a brain, it is also related to the work of electricity. The ability of a system or object to perform work is considered in physics to be "energy". In accounting theory, this ability of assets is called "capital", and it is the most important and measurable economic category. Theories and accounting systems focus on the measurable value of capital contained in objects or assets. Capital is embodied in the assets that make them measurable, expressed by the fundamental identity of double-entry accounting [2]. The doubleentry form of recording business transactions is due to an inability to create of capital. Capital can only be transferred, and its concentration increases the value of an object. In the economy, capital is mainly transferred through labor.

Contemporary theory of capital [3] points out that labor and capital are complementary-labor represents the dynamics (i.e., the transfer of capital from a source), and capital is the potential ability to perform work. Thus, the scientific approach to laborism rejects the determination of capital used unwisely as machines, money, real estates, which leads to conceptual confusion. Laborism respects the correct layout of concepts: assets, and capital accumulates in the assets through transfers called "labor" or "work". Thus, the measurability of capital is due to the measurability of work. The measurability of the assets and their value is derived from the contents of the capital in these objects. The category of resources remains unchanged; resources are countable only in natural units and not measurable in units of labor. Assets are measurable due to embodied capital.

\section{The Idea of Laborism at the Beginning of Civilization}

The theory and measurement of work in the physical sciences developed on the basis of heat engine research, along with the theory of thermodynamics; however, in the economy, work has been a subject of measurement from early millennia. The problem of the organization and measurement of human work in teams emerged naturally from the beginning of civilization. As M. Sliwa and M. Dobija explain, [4] “...it starts at the point when human beings first encountered the problem of how to work collectively, be able to achieve advantages thanks to the specialization and co-operation, and how to divide the effects of the work proportionally to the contribution of individuals.” Archeologists D. Schmandt-Besserat ([5]: 51-93) has shed much light on the origin of writing and counting as well labor accounting. She noticed a large number of small clay artifacts of various shapes which she refers to as "tokens". Plain tokens appear from ca. 8000 B.C. onwards. Figure 1 presents various tokens from Mesopotamia (Iraq), ca. 4000 B.C. The cone, spheres and disk represented various measures of grain; the tetrahedron stood for a unit of labor. 


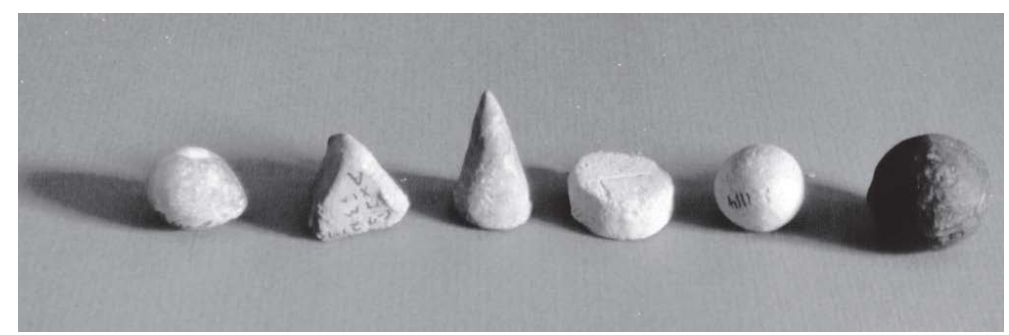

Figure 1. Different clay tokens. Source: Courtesy Denise Schmandt-Besserat, University of Texas at Austin. Schmandt-Besserat D., (2007, p. 3), When Writing Met Art. From Symbol to Story, University of Texas Press.

As R. Mattessich ([6]: 4-5) explains, the clay tokens were preserved in fired clay envelopes (hollow clay balls) around 3250 B.C.

"Soon afterwards, around 3200 B.C., the accounting tokens were impressed upon the outer surface before putting them into the envelope, and sealing them later. This not only enabled the recognition of the token content without breaking the envelope, it also introduced a double recording in so far as the same quantity was recorded twice (...) During the third millennium B.C. further accounting innovations can be found. Apart from introducing labor and cost accounting, agricultural and real estate accounting, budgeting, etc. the clay envelopes were abandoned and replaced by flat clay tablets to be impressed by tokens which then merely transferred symbols, but had no longer representative meaning on their own. ..."

Early accounting of labor with tokens is explained in greater depth ([7]: 15-42). According to archaeological evidence and interpretations of clay tablets containing records of labor performed by different group of workers, an economic system driven by labor already existed in the $3^{\text {rd }}$ millennia B.C. V. Struve [8], who examined organization of labor in Sumer (documents from the archives of Lagasz and Umma), claims:

"Tablets contain records of the numbers of laborers, male or female, as the case might be, who were to perform one or several tasks connected with agriculture, under the supervision of the overseer. The time assigned for the performance of each labor operation is sometimes estimated in days, and sometimes in months; but in the majority of cases it is given as one day: (so many laborers for one day). The meaning of this formula occurring in these small documents, which I called primary was fully revealed as a result of comparative analysis of the large reports of the overseer compiled on the basis of the primary documents, recording work performed by the laborers of their gang during a certain period. (...) From this I inferred that the Sumerian accountants had a notion of man-day.”

Therefore, it is clear that those accountants computed costs of labor in man-days. What is more, V. Struve [8] found that "In addition to the unit of labor force, the scribes distinguished such quantities as 5/6, 2/3, 1/2 etc. of a unit of labor force. The laborer whose productivity of labor was estimated at 5/6, 2/3, 1/2 etc. of a unit of labor force, received grain ratios proportionately reduced."

A. Tyumenev [9] examined working personnel on the estate of the temple in the town-state of Lagasz and found that the accountancy documents in $25^{\text {th }}$ century B.C. show a more developed system of economic records. "The documents mainly contain, on the one hand, inventories and descriptions of fields and land exploited for various purposes, list of labor personnel and reports accounting for it use, and on the other hand, records of incoming and outgoing goods, in particular, of the natural produce issued as rations to the personnel of the temple estate.” The last group of documents provides information about the labor force employed and the cost of labor measured in grain rations as explained by V. Struve.

Recording of labor and calculating adequate rations was an important part of economic activities in the beginning of civilization. Management control and audit activities were also present and well-developed in those times, as one can see in G. Roux ([10]: 117-117), who writes:

"All this required the planning, control, accurate accounting, but the Sumerians, meticulous and practical people, they were well organized in this regard. Their bureaucrats left us not only hundreds of payrolls, receipts, letters of employment and other such documents, but from the archives of Szurupak and Girsu we learn about extraordinary specialization Army of scribes increased by army of managers ugula, officers nu- 
banda, inspectors maskim, auditors agrig led by a person who was both a priest and a top manager of the temple sanga, meant that this severe economic machine works moothly.”

This ancient labor-driven economic system is elucidated in [11] by K. Polanyi and others. In antiquity, especially Sumeria, labor was accomplished within a civilized framework. G. Guyton [12] points out that: "The history of compensation for bodily injury begins shortly after the advent of written history itself. The Nippur Tablet No. 3191 from ancient Sumeria in the fertile crescent outlines the law of Ur-Nammu, king of the city-state of Ur. It dates to approximately 2050 B.C. The law of Ur provided monetary compensation for specific injury to workers' body parts, including fractures.” This proves that antiquity could be seen as a civilization of labor.

Thus, from the beginnings of civilization, we find issues of organization, management and measurement of work. Research by archaeologists and sum erologists suggests that the problem of measuring human labor was already solved thousands of years ago. To be effective, the labor of teams was required, inter alia, as was the objective measurement of work and earnings (work receivables) adequate to the value of the work. The fundamental idea of money is contained in laborism. Work receivable is the legal category, a derivative of work that is also abstract and measurable; it means an absolute right to receive the value equivalent.

At the beginning of modern economic thought, physiocrats such as F. Quesnay and others studied work processes. They considered the labor of industrial workers to be arid, because without support from the forces of nature it does not increase in value. The work of the farmer is an example of co-operation with the forces of nature (e.g., photosynthesis). This is the correct opinion, because in order for the work to be done, there must be an ability to implement it-namely, worker's human capital. Therefore, viewing the labor of the worker as merely the transfer of capital from existing sources to products does not increase the overall balance of values. That labor transfers only the earlier concentrated value into the personal human capital of the worker; however, this opinion was not correct if the second law of thermodynamics is taken into account, which shows the natural, random, spontaneous losses of capital contained in the assets. The labor of workers retains the natural loss of value, and it is an important factor in the overall balance.

\section{Laborism in Adam Smith's Economic Thought}

In the [Book I, Ch. V, 1.5.2], Adam Smith [13] wrote that:

"What is bought with money or with goods is purchased by labor as much as what we acquire by the toil of our own body. That money or those goods indeed save us this toil. They contain the value of a certain quantity of labor which we exchange for what is supposed at the time to contain the value of an equal quantity. Labor was the first price, the original purchase-money that was paid for all things. It was not by gold or by silver, but by labor, that all the wealth of the world was originally purchased; and its value, to those who possess it, and who want to exchange it for some new production, is precisely equal to the quantity of labor which it can enable them to purchase or command."

What a pity that present-day economies do not work in line with Adam Smith's paradigm of laborism. In practice, the accomplished labor creates work receivables, specifically money. Regrettably these words have not returned the economy to its natural state, where labor produces money so that the labor is self-financing. The phenomenon of self-financing is extremely advantageous for economies as it means that government needs not raise money to fund the public sector's payroll. Instead of collecting funds through taxation, an authorized government agency (e.g., the reformed central bank) makes appropriate transfer entries in the employees' commercial bank accounts. The only constraint is the size of the public sector.

The self-financing of labor means that labor is an exclusive process that may produce money as evidence of the labor done and represented by laborers' receivables. In the case of a company, its products need market approval; in other words, the company needs to make sales. In the case of the public sector units, however, their activities do not need the market approval. Instead, these activities are subject to a set of standards and procedures, such as those required in respect to teachers in a public school. To become teachers, individuals must accumulate enough human and intellectual capital to gain the ability to perform this labor-i.e., the tasks of a teacher. While teaching, they transfers their human capital to the pupils, who gain value as future workers in society.

Adam Smith can be perceived as the father of laborism since he unmistakably described the relation between the measure of labor and silver or gold coins. In [Book I, Ch. V, 1.5.7], he wrote: 
"Gold and silver, however, like every other commodity, vary in their value, are sometimes cheaper and sometimes dearer, sometimes of easier and sometimes of more difficult purchase. The quantity of labor which any particular quantity of them can purchase or command, or the quantity of other goods which it will exchange for, depends always upon the fertility or barrenness of the mines which happen to be known about the time when such exchanges are made. (...) Labor alone, therefore, never varying in its own value, is alone the ultimate and real standard by which the value of all commodities can at all times and places be estimated and compared. It is their real price; money is their nominal price only.”

Under conditions of laborism, people can use coins for their comforts, even banknotes; however, in line with laborism, money is the "work receivable" that arises as an effect of labor. Coins or even banknotes can serve to keep value determined by the work receivable in a pocket or apartment. In a real system of laborism, money cannot be produced by any “central bank”. Abstract categories such as labor, capital, and work receivables (money) create a triad that serves as the theoretical foundation for laborism.

In laborism, economic considerations focus on the inputs of labor and the work contained in the assets. The value of products and assets is proportional to the measure of inserted productive work. Market confrontation of total labor expenditures with the market price of product during the exchange is the moment of truth, in which reality is the only judge of final verification. Therefore, the exchange value is highly important in classical economics and laborism. This category features a strong, constant relationship between theory and practice.

After this brief analysis of how the writings of A. Smith are embedded in laborism, it is important to mention the contribution of the following authors. K. Marx did not, in my opinion, achieve a clear understanding of the fundamentals of laborism, due to the unclear kinship between the categories of labor and capital, and their complementariness. Indeed, K. Marx opposed these categories in his deliberations, and thus his theories did not lead to the expected results, as has been confirmed by practice. According to M.A. Lebovitz ([14]: 4-4), Marx recognized:

“...that in order to understand capital, we need to understand money. Commenting that bourgeois economists had never even attempted to solve the riddle of money, Marx demonstrated in his opening chapter (The Commodity) that the secret of money is that, as the universal equivalent of the labor in all commodities, it represents the social labor of a commodity-producing society. By this logic, then, M-C-M (Mmoney, C-Commodity) represents a process whereby capitalists, who own the representative of a portion of society's labor, are able to obtain a claim on more of that labor via exchange...”

This claim is a mixture of logic, legitimate speculations and obvious views. At that time, when Marx's theory of labor was published, thermodynamics could not serve as a canon of knowledge of reality. The key theory for his considerations of the measurement of employees' human capital, which Marx rightly considered as the "ability that performs labor," did not yet exist. The same was true for the possibility of calculating the fair wage. Even the theory of measurement of profit, which now supports accounting theory, was not yet available. Therefore, despite good intentions, the contribution of K. Marx to laborism does not significantly enrich A. Smith's achievements.

\section{Scientific Fundamentals of Contemporary Laborism}

The economic considerations take into account emergent properties such as human behavior, actions in own interest, the category of property, beliefs in the force of a currency, and decisions affecting the demography. That is why economics is considered to be emergent in relation to the physical sciences. The Stanford Encyclopedia of Philosophy ${ }^{1}$ defines emergent properties and laws as "systemic features of complex systems governed by true, law like generalizations within a special science that is irreducible to fundamental physical theory for conceptual reasons. The macroscopic patterns in question cannot be captured in terms of the concepts and dynamics of physics.” Laborism, although it is closely related to labor-i.e., the fundamental notion of physics-generates its own theory on the measurement of labor accomplished by employees, the measurement of personal human capital as a source of work, and equivalent compensation.

\subsection{A Method for Measuring Labor}

The formula for measuring work, applied in physics, presented in a simplified scalar notation (without vectors)

${ }^{1}$ Center for the Study of Language and Information (CSLI), Stanford University, Library of Congress Catalog Data: ISSN 1095-5054. 
shows two equivalent models. In this simplified scalar description, the measure of labor is:

$$
L=F \times s \times \cos \varphi=F \times v \times t \times \cos \varphi=P \times t \times \cos \varphi
$$

where $L=$ scalar mechanical work; $F=$ scalar force; $v=$ speeds calar; $\cos \varphi=\operatorname{cosine}$ of the angle between direction of force and direction of movement; $P=$ scalar of power; and $t=$ time of completion of work;

In economic practice, particularly in employment contracts, commonly, though perhaps unconsciously, the formula containing the second part of Equation (1) is applied with the category of power and the passage of time. Assigning an employee a rate of payment due to assigned responsibilities, among many others job positions, is the determination of the potential power $(P)$. If an employee is assigned to a position paying $\$ 3000$, and the highest salary is $15,000 \$$, the power factoris1/5and180 hours of work per month is equal to $91 / 5 \times 180$ ) $=36$ units of labor. By this account, 36 labor units $=\$ 3000$, so $1 \$=0.012$ basic unit of labor. It does not matter in the economy what part of the 1 labor unit is $1 \$$. This unit is adopted as the basis of economic calculations, the dollar is just a common unit of labor. Since the power coefficient is determined as the quotient of wages, the measurement of labor in the economy can be described as follows:

$$
L=P \times t \times \cos \varphi=W / W_{\max } \times t \times \cos \varphi=H / H_{\max } \times t \times \cos \varphi
$$

where $W / W_{\max }$ denotes individual wages and $H / H_{\max }$ denotes personal human capital of examined employees. Self-control of an individual and managerial control make it possible to assume that $\cos \varphi$ is equal to 1.0.

Since economics is still emergent in respect to physics, additional interpretations are needed. As we know, if the direction of the force is not in line with the direction of the predefined path, the force vector is corrected by the tilt angle of $\cos \varphi$. The size of the $\cos \varphi$ in economics is usually overlooked, though that is not entirely appropriate as it indicates the extent to which the work was done efficiently. Work in the context of economics is done in order to achieve managerial and social goals. If a gang of thugs destroys a bus stop, they also do the job, but in opposite direction, so $\varphi=180^{\circ}$. Hence, $\cos \varphi=-1$. Counting properly when measuring GDP, the work of the thugs with a negative sign ought to be added first, then the positive value of the labor of a repair team. Then, the impact on GDP would be close to zero, while today only the work of the repair team is counted.

Work measurement provides measurability to other economic values, especially capital, and thus the possibility of identifying, measuring and reporting in order to control the economic system; however, labor only transfers the capital located in objects, particularly inherent in employees and assets, to products of all categories. Thus, in the economic computations performed ex post, there is only the value of the employees' current work and the value of work concentrated in all sorts of assets. The influence of natural forces is omitted.

Laborism is therefore a mainstream of economic thought, which focuses on inputs, i.e., labor. Y. Ijiri [15] writes with respect to accounting, which is an important part of this concept:

“...In contrast to the labor theory of value, which focuses on input, the utility theory of value focuses on output; hence, it does not question how and through what process a product was produced as long as the output possesses the same use value. Thus, the cost principle would not have a common linkage with the utility theory of value as it does with the labor theory of value..."

Other authors such as R.A. Bryer [16] have proven that Marx's theory of value is superior to the marginalist theory of value in the case of financial reporting. Therefore, laborism can be seen as economics driven by labor. A completely different approach to economics is the concept of utility theory, which has a different concept of value primarily focused on the product (output). It should be emphasized that this theoretical approach is currently prevalent in the economic literature; however, practice is absolutely dominated by information from the economics of labor. Thus, laborism can be seen as a system of knowledge, or science, which applies the paradigm of labor and capital as the ability to perform work. Money is generated in the work process. The economic value of assets of any kind is determined by the concentration of the capital transferred through work. Scientific studies examine cognitive and decision-making problems in the field of labor and capital measurement in order to maintain the balance of economic systems, i.e., their ability to protect their own interest and their ability to control their own interests.

\subsection{Economic Constant of Potential Growth}

The sciences use some special numbers known as constants [17]. These constants are indispensable in the sciences. They serve as a link to unknown knowledge of a higher rank. Models anchored by constants serve 
perfectly in the theories of gravity or quantum mechanics, for example; however, the constants themselves, as is commonly known, have no theory. They are recognized only by measurement. In economic considerations as well, a constant is known as a special number that is determined mathematically without any theoretical explanation. Laborism sheds some light on this matter and makes for a wider field of research. We consider four cases-honest interest rate, risk premium, mean value of rate of return (ROA), and the fair minimum wage-as domains of an economic constant.

(I) In the days of the Republic of Rome, we find traces of disputes between creditors and debtors as well as the legal decisions. According to A. Pikulska-Robaszkiewicz ([18]: 41-42), in the Republic of Rome, the legal rate of interest, taking into account the interests of the parties and the nature of the environment, was defined as $1 / 12$ of the initial capital, i.e., at the level of $8.3 \%$.

(II) In economics, particularly finance, there is a number that was called the "market risk premium" or "premium from the capital”. There are publications like [19] and many others, in which the authors seek to estimate the size of this premium, perceived as an appropriate rate of return on invested capital. In fact, the authors examine the percentage rate of return over the risk-free rate. The latter is usually defined as short-term government bonds; however, not everyone accepts that there is a risk-free rate, and then it is simply the rate of return. A significant historical study and investigation of the size of the risk premium achieved by investing in shares is presented by R. G. Ibbotson and W. N. Goetzmann [20]. These estimates are used in this study, but with my own interpretation as shown in the Table 1.

Row 4 shows the average real rate of return on the shares computed from data on 1926-2004. Row 5 presents the differences between the real returns on stocks and government bond T-Bills. We see that the real value of the T-Bills is close to zero. Assuming that there is no real opportunity to invest without any risk, we interpret the size of $8.33 \%$, which is a simple arithmetic average, since $9.27 \%$ and $7.39 \%$ are credited with equal probability. Let us note that if we say that there exists an a priori potential rate of return $p$, and $p=8 \%$, or 0.08 [1/year], which expresses the rate of accumulating initial capital, then the value of investments in the amount of one dollar should be multiplied up to $1.0 \times\left[\mathrm{e}^{0.08}-1\right]=0.083287 \approx 0,0833$; therefore, the estimated $\mathrm{p}$ value should be equal to $8.33 \%$. Now, we can discern compliance to two decimal places with the average value in line 4 . This high consistency is likely coincidental, but calculations show that the estimate is significant.

(III) Another study on the size of the rate of return was conducted in the field of entrepreneurship by B. Kurek [21] whose estimations largely refer to the previous ones. B. Kurek adequately defined the ratio ROA as the ratio of profit (capital increase) to total capital included in the assets of a firm. Field studies examined the balance sheets and income statements of companies belonging to S \& P's 1500. The author had access to the reports of 1500 companies over a time period of 20 years; however, the actual number of reports in the Compust at database was 22,952 statements. The author conducted a statistical survey based on the hypothesis that the average risk premium calculated with the ex post data is equal to $8.33 \%$. The survey results do not reject the hypothesis. The confidence interval at confidence level 0.99 is $8.25 \%-8.89 \%$, while the mean is $8.57 \%$ with a standard deviation of $14.81 \%$. Assessment of the relative error does not exceed 5.0, since the relative precision of the estimation equals $3.75 \%$, which indicates that the statistical forecasting is safe. This author also examined reports for smaller collections, such as S \& P's 600 (small businesses) and S \& P's 400 (average), which yield similar results—on average $7.41 \%$ and $8.85 \%$, respectively, but with a greater error evaluation, not excluding the statistical forecasting.

Table 1. Average rates of return in the United States, 1926-2004.

\begin{tabular}{|c|c|c|c|c|}
\hline & Variable & Arithmetic average & Geometric average & Standard deviation \\
\hline 1 & Stocks & $12.39 \%$ & $10.43 \%$ & $20.31 \%$ \\
\hline 2 & T-Bills & $3.76 \%$ & $3.72 \%$ & $3.14 \%$ \\
\hline 3 & Inflation & $3.12 \%$ & $3.04 \%$ & $4.32 \%$ \\
\hline \multicolumn{5}{|c|}{ Computations } \\
\hline 4 & $(1)-(3)$ & $9.27 \%$ & $7.39 \%$ & Average 8.33\% \\
\hline 5 & $(1)-(2)$ & $8.63 \%$ & $6.71 \%$ & Average $7.67 \%$ \\
\hline
\end{tabular}


(IV) The question naturally arises of how to calculate the capital contained in human resources? Let us examine the calculation of the minimum wage in the United States using $8 \%$ as the constant. It is assumed that the legal minimum hourly wage in the United States is determined at an honest level, which allows protection against the depreciation of human capital. Currently, this wage is US $\$ 7.25$. Together with the pension contribution, this gives $7.25 \times 1.062=$ US $\$ 7.70$, since the employer pays a pension payment of $6.2 \%$. It is assumed that a teenager (17 years old) grew up in a family of four people type $2+2$. According to the survey, an estimated value of monthly costs of living belongs to the interval [450\$, 500\$]. The amount of $\$ 475$ per person per month is chosen for our computations. The number of years of capitalization is 17 . The calculations are placed in Table 2. These computations also provide a simple test of whether the value of the economic constant of potential growth (ECPG) is 8\% provided that US minimum wage is fair. The potential value of a teenager's human capital joining the work force at 17 is calculated by capitalizing the costs of living (while ignoring the baby, who is a natural good and thus not subject to economic calculation). The estimated human capital is 206,354 USD.

Compensation for the entrepreneur is the cost of the use of the human capital. Since capital as an abstract and potential category relies on natural dispersion, the value of human capital requires compensation equal to the expected diffusion with ratios. The scattering of capital is spontaneous and random. Its average value does not exceed $p=0.08$ [1/year]; otherwise, destruction would overcome creation. Therefore, yearly compensation $W=$ $s \times \mathrm{H}(p) \approx p \times H(p)=16,598$, where $\mathrm{s}$ determines the rate of random dispersion of capital, and $H(p)$ denotes human capital. As a result, the calculations show almost $100 \%$ consistency between the remuneration arising from the theory and practice of the real minimum wages. A change of the ECPG by about plus or minus 0.005 leads to excessive deviations. Assuming as that the minimum wage in the United States is a fair value, it is concluded that the value of the constant $p$ appearing in the formula $W=p \times H(p)$ should be $p=0.08$ [1/year].

The second part of Table 2 confirms that the constant pay determined by the formula $W=p \times H(p)$ as well as the real mandatory minimum pay are fair, which is to say that this wage prevents human capital depreciation. This opinion is confirmed by various studies, such as W. Kozioł [23] and J. Renkas [24]. If the minimum wage is $1.376 \$$ per month, the two parents earn at least $2.752 \$$. After paying pension contributions of $20 \%$ and $10 \%$, the health monthly fee remains at $1.926 \$$. So, for the four-person family $(2+2)$, the cost of living is at least 481.6 USD per person. This is more than the initial value of $475 \$$, so the conditions of life are not worsening even at the absolute minimum wage. The pension contribution of $0.2 \times 1376 \$$ or $275.2 \$$ capitalized at the real rate of $3 \%$ to 65 years of age or over 47 years will provide the pension fund with $331549 \$$, which gives a monthly pension at the minimum wage level for the next 20 years.

The above four areas of testing point to the existence of a potential of Nature, which is determined by constant called the "ECPG". As mentioned before, this kind of parameter has not a theory but only numeric value. They are well known in mathematics, physics, and chemistry, where they fulfill an indispensable role. It is worth recalling that the first constant discovered was $G$, the galactic constant, which helped to determine the gravitational acceleration $g=9.81 \mathrm{~m} / \mathrm{s}^{2}$. Scientists have different interpretations of the phenomenon of constants; some believe that these figures will disappear when the theory develops accordingly. J. Barrow ([17]: 290-229), who wrote a book about the role of constants in explaining reality, wrote in the conclusion:

Table 2. Computations of human capital and introductory test whether ECPG $=0.08$ [1/year].

\begin{tabular}{|c|c|c|}
\hline Computed value & Computation formula & Issue \\
\hline Capitalized cost of living at rate of $8 \%$ Continuous compounding & $H(p)=12 \times 475\left[\mathrm{e}^{17 \times 0.08}-1\right] / 0.08$ & $\$ 206.354$ \\
\hline Yearly cost of labor of teenager & $W=s \times H(p) \approx p \times H(p)$ & $\$ 16.598$ \\
\hline Monthly cost of labor & $\mathrm{MCL}=\mathrm{W} / 12$ & $\$ 1, .76$ \\
\hline Computed hourly cost of labor (HCL) & $\mathrm{HCL}=\mathrm{MCL} / 176$ & $\$ 7.81$ \\
\hline The legal HCL increased by the employer pension & $7.25 \times 1.062$ & $\$ 7.70$ \\
\hline \multicolumn{3}{|c|}{ Family $(2+2)$ revenues } \\
\hline Doubled minimum wage & $2 \times \mathrm{MCL}$ & $\$ 2.752$ \\
\hline Minus contribution for pension fund (20\%) and health care (10\%) & $0.3 \times 2.752$ USD & $\$ 1.926$ \\
\hline Cost of living per person & $1926 \mathrm{USD} / 4$ & $\$ 481.60$ \\
\hline Detriment fund for 1 person after 43 years capitalized at rate of $3 \%$ & $12 \times 275.2 \times\left[(1+0.03)^{47}-1\right] / 0.03$ & $\$ 331.549$ \\
\hline
\end{tabular}

Source: Computation at current data as presented by M. Dobija [22]. 
"Our discovering of the patterns by which Nature works and the rules by which it changes led us to the mysterious numbers that define the fabric of all that is. The constants of Nature give our Universe its feel and its existence. The constants of Nature are the ultimate bulwark against unbridled relativism. They define the fabric of the Universe in a way that can side-step the prejudices of a human-centered view of things. If we were to make contact with intelligence elsewhere in the Universe we would look first to the constants of Nature for common ground.”

This explanation is extremely important. The constants exclude all rampant relativism. Adversaries in the social sciences are generally unable to agree and each present their own narratives. In various sciences, researchers arrive at recognized theories and computational methods which ensure the effective implementation of projects and the progress of civilization. ECPG enables the measurement of human capital and the creation of the theory of fair remuneration. Moreover, it indicates the reasonable size of the rate of profit, as well as the interest rates and discount rates. This constant is also an important component of the general capital model. The ECPG works against unbridled relativism.

\subsection{The Economic Constant as a Profit Factor}

The estimation results and the concept of the ECPG lead to questions about the source of income and profits. It is clear that profits on the shares have a source in corporate profits; this correlation is comprehensible. Enterprises calculate the depreciation of fixed assets, and they usually pay fairly for work of human capital, which in both cases does not allow the depreciation of applied capital. Companies pay for supplies and also pay taxes to the external environment. We may find that reasonable management leads to a state in which all contractors of companies obtain an appropriate part of the created surplus. If we do not admit any mistreatment, then what is the source of profits? Of course this is not like risk, which is the source of unforeseen costs and losses. The answer is obvious; this potential mainly lies in Nature. Together with human labor, it allows for the reproduction of capital and the creation of surplus value, as the Physiocrats already stated.

The initial capital invested in the economic process is affected by three factors: the natural dispersion that randomly causes initial value to decline; transfers by labor that increase the initial capital; and the economic constant, which indicates a reason why the initial capital and human sources exist, so that the labor can be accomplished. In the economic process, labor reduces after all the influences of the inescapable dispersions, then increases the initial value. The constant represents the forces that make the labor possible. This constant represents Nature where the phenomenon of photosynthesis manifests itself, which uses solar energy to produce carbohydrates. Thanks to photosynthesis, the plants can develop as well the animal kingdom that relies whether directly or indirectly upon this source of nutrition. Therefore, human resources maintain their existence. The human capital, which is doing the work by transferring itself to work objects (products) is embodied in these resources. As Table 2 shows, the measure of human capital is a function of the material outlays, flow of time, and the economic constant.

That is why R. Wright ([25]: 30-32) could discern the economy as a game with Nature, which is a positive non-zero game where all participants can take part in the win. The size of the win estimates the constant of potential growth at the rate of 0.08 [1/year] of the initial capital. This means that the capital which is embodied in resources of various kinds can multiply at a yearly average rate of $8 \%$. This constant called the "economic constant of potential growth" characterizes the human existential space and determines the proper rate of capitalization of expenditures that form the value of human capital as a labor resource.

\section{The Human Capital and an Equitable Constant Remuneration}

The measurement of human capital of workers and determination of the fair remuneration for the work belong to the central issues of laborism. Having determined the value of the capital, affair constant wage is determined by natural application of the second law of thermodynamics. Thanks to P. Atkins ([26]: 157-159) is known that many biochemical processes in a human body work according to the theory of a heat engine. Therefore the body may be discerning as the heat engine, which cannot work without loss of internal energy. Hence, it is known that an employee loses human capital spontaneously even without doing a professional job. In order to preserve this capital the minimum wage should balance the natural loss of employee's life forces.

Even the thermal efficiency of the heat engine $(e)$ as designated by S. Carnot applies almost directly to the living individual. $H$ is astonishing formula ([1]: 52-53): $e=1-T \sin k / T$ source where the $T$ sink $=0$ denotes ab- 
solute zero of the surroundings, and the T source denotes the absolute temperature of the source of the heat (natural temperature of the body) warns us about dangers of bringing to a halt our engines. An individual loses life $(e=0)$ when $T \sin k=T$ source i.e. the both temperature is about 37 Celsius degrees. Thus the workers doing their job in the higher temperature need special protections.

If coefficient (s) denotes the natural spontaneous loss of capital, the fair pay $\mathrm{W}$ is determined by formula:

$$
W=s \times H\left(p, t_{1}, t_{2}, T, w\right)
$$

where: $H\left(p, t_{1}, t_{2}, T, w\right)$ denotes employee's personal human capital, $p=$ ECPG $=E(s)=0.08$ [1/year], $t_{1}-$ number of years of life to start of professional job, $t_{2}$-number of years of professional education, $T$-number of years of employment, $w$-parameter of learning ability. The pattern (3) expresses idea that the fair pay balances natural loss of employee capital because a payment at this level is sufficient to cover natural dispersion. Taking into regard that the (s) is a random variable and $p=E(s)$, the Equation (3) is applied in form $W=p \times H\left(p, t_{1}, t_{2}, T, w\right)$. This formula is tested from nineties by examining wages in many countries [22]-[24].

A general model of human capital measurement can be introduced in convenient form as follows:

$$
H(T)=K+E+D(T)+R
$$

where:

- $H(T)$ —denotes measure of employee's human capital (EHC) with $T$ years of professional work;

- $K$-capitalized cost of living at rate $p=0.08$ by n years, up to achieving the capability of doing professional work;

- E-capitalized cost of professional educations at rate $p=0.08$ by $\mathrm{m}$ years, until to achieving the capability of doing professional work;

- $D(T)$ experience capital, $D(T)=(K+E) \times Q(T)$, where $Q(T)$ is adjusted learning curve formula [22];

- $R$-a creativity capital determined eventually utilizing market values.

Testing the EHC measurement model is carried out via wages determined on the basis of the equation (3). The basis of the empirical tests is the real constant wages of employees' or information obtained in the centers for people looking for jobs.

One of the economic theories of remuneration points out to the level of human capital as the most important factor. This principle can be derived formally using internal rate of return concept. The equation of the internal rate of return (IRR) written for EHC for period of one year allows for determination the total remuneration $W$ as a function of EHC. The IRR equation is as follows:

$$
H(T)(1+r)=W+H(T+1)
$$

where $W$ denotes the yearly remuneration and the $r$ is a rate of return.

From the Equation (5) results formula of the variable $W$ :

$$
W=H(T)(1+r)-H(T+1)
$$

Now applying Formula (4) of the $\mathrm{H}(\mathrm{T})$, the Equation (7) is formed:

$$
W=r \times H(T)-[D(T+1)-D(T)]=r \times H(T)-\Delta D(T)
$$

This means that the remuneration is determined as a fraction of EHC, but it is reduced by the growth of work experience $D(T)$ in the current year of work. For a fixed wage (salary) this percent is well known; on the basis of knowledge that determines the fair wage the $r=p=$ ECPG $=0.08$ [1/year]. Reducing wages by $\Delta D(T)$ is natural and universal, because an employee gains experience as a side effect of the work, and an organization provides a place of work. This reduction is greatest at the beginning of employee's career, when the experience grows fastest. The $\Delta D(T)$ tends quickly to zero.

Thus, the formula of fixed remuneration comprises the ECPG twice, since it applied in the form $W=p \times H(p, T)$. Research made confirms that such a formula protects philosophy of wages against uncontrolled relativism mentioned by J. Barrow in his work on the role of constants in scientific description of the world. It is known, that Plato already indicated that the range of wages should not exceed 5 times. According to calculations of human capital the range of fixed wages (but without considering a creativity capital) should adhere to such ratio; no more than 6 . This principle is often broken now. For example, in Poland the number resulting from dividing av- 
erage earnings in groups of $10 \%$ with the highest and the lowest earnings is 10 times. In case when exists an identifiable creativity capital of an individual the earnings can be very high but such an event is theoretically consistent.

\section{Laborism and a Suitable Model of the Production Function}

The possibility of assigning value to the human capital of employees opens a way to the formulation a production function as well as production model adequate to laborism. If $L$ denotes a fair fixed wage, and $H$ is personal human capital of workers so the product $L=p \times H$ ( $p=$ ECPG) helps to determine the value of the $H$ [27]. On this basis, the production function is constructed and subsequently the adequate production model. The production function reveals a factor of labor productivity $Q$, which has outstanding applications in economics.

Production function comprising the measurable variable $H$ takes into account the criticism of the econometric modeling of production as expressed by J. Robinson [28], who wrote the following critical opinion:

“... The production function has been a powerful instrument of miseducation. The student of economic theory is taught to write $Q=f(L, K)$ where $L$ is a quantity of labor, $K$ a quantity of capital and $Q$ a rate of output of commodities. He is instructed to assume all workers alike, and to measure $L$ in man-hours of labor; he is told something about the index-number problem in choosing a unit of output; and then he is hurried on to the next question, in the hope that he will forget to ask in what units $K$ is measured. Before he ever does ask, he has become a professor, and so sloppy habits of thought are handed on from one generation to the next...”

Production $P$ at the market price is a product of the total costs $C$ and an average ratio of cost profitability $r$, so:

$$
P=C(1+r)(1+I)
$$

where index $I$ is a return above average rate of the cost profitability (manifestation of the organization intellectual capital). The $(r)$ by definition is a quotient of the surplus of production market value $(N=P-C)$ to the total cost $(C)$, so that $r=N / C=P / C-1$. When the index $I>0$, then the company generates a value called intellectual capital. The ratio $r=N / C$ is the cost profitability ratio and it is the function of two variables: return on assets ROA, $(\mathrm{ROA}=N / A, A-$ total assets) and the total asset turnover computed according to the costs $C$. Since the total asset turnover is $w=C / A$, we get $C=w \times A$. Therefore, the ratio $r=N /(w \times A)$ or ROA $/ w$.

The cost $C=W+B$, where: $W$-labor costs, and $B$-remaining costs determined by technology and the management process. Subsequently $B / A=z$, so $B=z \times A$, where $z$ is the asset turnover according to cost $B$. Thus, we can write the following formula:

$$
P=(W+Z \times A)(1+r)(1+I)
$$

where: $A$-assets expressed at historical, balance sheet prices. After rearrangement, the production market value is as follows:

$$
P=W[1+(A / W) \times z](1+r)(1+I)
$$

Since labor costs $W$ are a derivative of human capital, then $W=u \times H$, where: $\mathrm{u}$ is the rate of payment of human capital, and $H$ is the total value of the human capital employed. After substitution the following formula is obtained:

$$
P=W[1+(A / H) \times(z / u)](1+r)(1+I)
$$

The values $r, I$ are small, close to zero, thus using the approximate equality: $1+x \approx \mathrm{e}^{x}$, we can express the production function with the following formulas:

$$
P=W \mathrm{e}^{r+I}[1+(A / H) \times(\mathrm{z} / \mathrm{u})]=W \times Q
$$

where $Q$-dimensionless value determining labor productivity of an organization.

The labor productivity $Q$ is a very important variable that helps to solve micro and macroeconomic problems. In particular the $Q$ is useful for determination of bonus pay in consistency with economic performance of a company [29]. On the basis of the production function (Equation (12)) is formed a production model by utilizing formulas $\mathrm{e}^{a}$ 
$\approx 1+a$. Then substituting for set of variables $(r, z, I$, and $u$ ) a one synthetic variable $M$ (called management) we get the model of production. This variable $M$ synthesizes impacts of the mentioned short-term variables that are subject to the current managerial decisions opposing to the long-term variables such as assets $A$ and human capital $H$. The model is as follows:

$$
P=W \times \exp \left[\frac{A M}{H}\right]
$$

Now, utilizing formula $L=p \times H$, where $L$-value of constant pay, and $p=0.08$ [1/year], we eliminate the variable $H$ by easier accessible variable $L$. Then the model is:

$$
P=W \times \exp \left[\frac{A M p}{L}\right]
$$

Model determined by the Equation (14) is useful in computing the fund for compensations over the fixed wages or salaries that is to say the bonus compensations. Assuming a natural condition that the variable $M$ ought not to decrease, which means that the profitability of the cost and speed of rotations of assets are maintained, despite a possible increase in wages, we get the equation (15) with the one unknown variable $W$. Thus, the formula for determining the total amount of earnings is as follows:

$$
W=P \times \exp \left[-\frac{A M p}{L}\right]
$$

The Equation (15) allows for determining the remuneration budget as a function of the premeditated economic performance. If a budgeted production and sale will be accomplished at the not less variable $M$, the amount $(W-L)$ determines the size of the bonus fund. Therefore a level of variable $M$ calculated for the first year is the starting point. For budgeting purposes, it is assumed that the $M$ in the next year cannot be reduced what makes it as a given parameter. Of course, a management may adopt a policy of systematic increase in that variable. This will mean that the profitability of costs and the turnover ratios will not decline, as well the fixed pays rises will be adequate to the financial results of organization.

In addition the $Q$ forms an important relation as follows.

$$
Q=\mathrm{e}^{\frac{A M p}{L}} \text { and } Q=\mathrm{e}^{T M}
$$

Here the variable $M$ is an equivalent of the well known category called TFP (total factor productivity), $L$-fixed basic pays, and $T=A / L$ shows how the work is equipped in all sorts of assets.

From macro point of view the $\mathrm{Q}$ forms a relationship with GDP as follows:

$$
\mathrm{GDP}=\mathrm{GDP} \frac{1}{Q}+\mathrm{GDP} \frac{Q-1}{Q}=W+\mathrm{GDP}_{\mathrm{A}}
$$

where $\mathrm{GDP}_{\mathrm{A}}$ denotes a part of GDP belonging to assets. Thus, formula divides GDP into two parts. The first ( $W$ ) belongs to employees, and the second is assigned to assets. This sheds some light on GDP as the sum of all employees' earnings plus the part belonging to assets (depreciation + interest + rents + appropriate part of companies income) and it correlates to the cost method of measuring GDP.

The above introduced function and the model are useful in both microeconomic and macroeconomic agendas of an economy. Such variables as GDP, $Q$, and $L s=1 / Q$, where $L s$ is the labor share, belong to a key indicators of real economy. The greater labor share the poorer economy is a simple motion. The parity of the ratio $Q$ serves to estimation of exchange rate trend [30], and the $Q$ itself is a tool to control of inflation, as well is a determinant of credit level. Introduced production function is a tool of control of total pay in conformity to economic performance of an economy.

\section{Macroeconomics of the Laborism. Control of Inflation, Deflation and Credit}

\subsection{The Wage Equation of Exchange}

The essence of the real money-goods economy is a continuous market confrontation of two streams, which are activated by the potential of human capital and labor, as it is shown in Diagram 1. The first stream (left side) 




Diagram 1. Market as a mechanism leveling the value of product and money. Source: An extension of the diagram presented in the [31].

forms value of final products generated by composition of the current labor of employees measured by pays $(W)$, and the past work embodied in different sorts of assets. The second is the stream of compensations $(W)$, i.e. work receivables. The source of these two streams is the same human capital of employees, and their edge is the market exchange of money (work receivables) to products and vice verse. This exchange can be described in the form of the equation of exchange. The streams run constantly, but to capture the quantitative relations, we use variables in the annual scale, in particular of the GDP category.

The final production exchanged on market for a given year is the value of GDP in current prices. GDP can also be discerned as the product of $W$ and work productivity $Q$, i.e. GDP $=W \times Q$. The $Q$ is a factor of the cost production function, presented earlier. Many applications of the ratio $Q$ are included in paper [22]. A part of remuneration quantified by formula $a \times W$, where $0<a<1$, passes directly to market exchange. The second part of the pays stream $(1-a) \times W$ flows firstly to the system of commercial banks. These are savings and pension funds.

In the commercial banks this stream can be increased by multiplier $k$ to the volume of $(1-a) \times W \times k$, due to credits and payment of pensions. Some part of this inflow remains on bank accounts due to the requirements of bank liquidity and other provisions.

The market confrontation of these two streams (value of products and money) finally determines the purchasing power of money and the market value of products. Quantitative perspective of exchange of products for money (and vice versa) written in the form of the wage equation of exchange leads to indication of a relation between 
some introduced variables. The wage equation of exchange is introduced under condition that work finances on its own and generates money (work receivables), as well pension funds are a kind of savings.

Let us notice that Diagram 1 encompasses the work of every employee: farmer, worker, teacher or police officer who works both in the private and the public sector of economy. Diagram 1 helps also to see how the past work serves for future time. If some employees working in their profession were building bridges, they received money (their work receivables) recorded on their bank accounts and partly transferred to their pension funds. From other side the costs of their work became a part of the bridge value. Now, having already retired, they receive payments from the capitalized retirement funds, but in the stream of products there is an amount of depreciation of the existing bridges serving to the inhabitants. Similarly, the teacher and the policeman, who worked for a safe development of human resource, increased human capital embodied there. Now a work of this human capital currently increases GDP.

The wage equation of exchange balances the value of GDP with the sum of money M. According to Diagram 1, this equation is as follows:

$$
\mathrm{GDP}=\operatorname{GDPR}(1+i)=a \times W+(1-a) \times W \times k+\Delta S
$$

Symbols denotes as follows: GDP—nominal GDP, GDPR—real GDP, $W$-labor costs, $Q=$ GDP/W—work productivity index, $Q_{r}=$ GDPR/W-real work productivity index, $i$-inflation (deflation) rate, $a$-variable of poverty or prosperity, $k$ - coefficient increasing the value of stream $(1-a) W$ as a result of credit actions conducted by banking system, $\Delta \mathrm{S}$ change in saving level.

\subsection{The Adequate Level of Credit and Inflation (Deflation) Agenda}

On the basis of the equation (18) the multiplier $(k)$ is determined. A fundamental assumption is that $\boldsymbol{i}=\mathbf{0}$. It means the zero inflation and deflation conditions. Then the Equation (19) is obtained:

$$
\mathrm{GDP}=\mathrm{GDPR}=a \times W+(1-a) \times W \times k+\Delta S
$$

The Equation (19) divided by variable $\mathrm{W}$ gives:

$$
Q=Q_{r}=a+(1-a) \times k+d, \text { where } d=\Delta S / W
$$

Hence, the formula determining the multiplier of additional credit creation $k$ is as follows:

$$
k=\left(Q_{r}-a-d\right) /(1-a)
$$

Therefore, the adequate (required) credit level is determined by equation (22). In a primitive economy where GDP $=W$, the $Q=1, a=1$, and $\Delta S=0$ there is not a possibility of credit creation. A required level of credit is determined mainly by the real productivity of labor. The last step determines the adequate credit level for an economy described by variables: $W, Q_{r}, a$, and $d$.

$$
\text { Adequate credit level }=(1-a) W\left(Q_{r}-a-d\right) /(1-a)=W \times\left(Q_{r}-a-d\right)
$$

The credit level determined by the Formula (22) protects an economy from both inflation and deflation. Thus, this level of credit has to be achieved otherwise deflation may be a problem. The Formula (22) indicates only main macroeconomic variables, which have impact on the credit level generated by commercial banks system. Apart from these values there is a set of constraints, in particular the need for providing safety of a commercial bank, which also seriously limits lending. Institution called central bank is no longer a lender of the last resort. In theory of laborism the central bank is the payer of wages for the public sector.

The above considerations show that in the present economic system the central bank has to constantly issue new money, otherwise the imbalance would appear. A reason is the financing labor in the public sector by taxes as well the direct taxes declining employees earnings. The recent situation of yen, dollar and euro is a good example. Taking into regard cost of labor in the public sector it is possible a rough estimation of necessary issuance of money. Assuming the GDP in the USA, at the level of 16,500 billion dollars in 2014 and estimation of the index $Q=3.60$ we obtain the value of labor costs $W=G D P / Q=4583$ billions USD. Then, we calculate a part attributable to the public sector. This is unknown ratio. In Poland where budget sector is very big the ratio is estimated 0.23 . Applying slightly less ratio 0.21 the US public sector labor costs are $4583 \times 0.21=962.5$ billion dollars per year. Hence, the amount per month is 80.2 billion dollars. 
This is roughly estimated value that also flows by stream of products as shown on Diagram 1, but it is excluded from stream of money by direct taxation of employees earnings. This is a reason of constant excess of values in the stream of products (particularly at times of peace and lack of inflation). Therefore the quantitative easing, applied periodically by FED is justified, just like an opinion that without money printing economy will collapse by strong deflation. Calculations are to some degree consistent with a real practice. In December 2013 Forbes [32] informed that additional printing of dollars by FED will be limited: “... American FED decided to reduce the scale of purchase of assets (treasury bonds) to the level of 75 billion USD a month. (...) Reduction in the quantitative easing by 10 billion dollars a month is the first step towards withdrawal from additional money printing, which so far has fostered the USA economy...” The above information correlates with introduced calculations.

Laborism meets here with a concept of a helicopter money. As B. Bossone et al. [33] explains:

“...High debt and deflation have afflicted Japan, the Eurozone, and the US. However, the monetary and fiscal policies implemented so far have been disappointing. This column discusses the importance of helicopter money in the form of overt monetary financing in addressing these problems. Overt money financing is the policy with the highest impact in raising demand and output without increasing public debt and interest rates..."

A similarity to self financing of labor seems to be distinctive but laborism is supported by the fundamental laws, while the overt monetary financing is a remedy without a theoretical reflection. Such a financing is justified only to remuneration. Purchasing of assets should never be financed by the central bank.

Deflation affects only the economically developed and strong economies. Countries that finance their budgets by disproportionate emissions of money, without a close relationship with economic performances, usually have a weak currency and the high inflation. In order to avoid deflation, such a country authorities can simply conduct a carelessness economic policy. Then the labor productivity ratio declines and amount of the necessary credit is also less.

This is no way in developed economies, so their authorities conduct periodically the quantitative easing process, which improves economic relations. For some external observers this way of conducting the money matters may looks sometimes as a beginning of a currency war [34], since money of the foreign countries becomes stronger. Therefore the external countries have to launch a similar process tending to the economic stability. Theory of laborism indicates however that the right recipe for balanced economy is the fair payment for all the necessary, indispensable and useful labors without charging earnings by direct taxes. In addition the labor productivity should never decline.

\section{Concluding Remarks}

The paper contains composition of some old economic ideas, connected to the new research findings relating to labor accomplished in economic systems. This composition is a description of the essence of laborism, an economic theory that is focused on labor, fair compensation, and the sustainable development of the economy. Modern laborism is anchored on precise definitions and measurements of labor, capital, value, and money. What's more laborism does not allow anti-scientific concepts and activities, such as the formation of the money out of nothing. Money is generated by labor as payment for a work done (work receivables). Therefore is deemed that the work itself is funding (is self financing). Application of this knowledge is a source of many benefits to the economy. Labor self financing eliminates the budget deficit without raising taxes. Implementation of laborism leads via reform of the central bank, which becomes the payer of salaries for the public sector of an economy.

Laborism also defines the rules to make the credit. The theory explains that in order to maintain stability of the currency unit (the unit of account, the unit of work) the credit not only can, but must be granted in the appropriate amounts. This is a new issue for theoretical studies and practical solutions, because the economy may have difficulty in absorbing the lot of the loan. Money-goods economy needs appropriate amount of credit otherwise a deflation or an inflation will appear. The deflation is a mark of too less amount of credit. The first remedy is the fair payment for each indispensable useful work in economy (salaries for mothers among others) without decreasing earnings by direct tax.

A general implementation of laborism opens the way to more smooth international cooperation because of the disappearance of the national currencies emissions, and therefore increasing economic stability in every aspects. 
Some economic policy initiatives will meet a more fertile ground for example a formation of the integrative currency areas in which coexist richer and poorer countries, as discussed in [35] [36]. In such an area, depending on the level of labor productivity of the national economy, for the same work employees may receive less or more money, but in the same units of work. This situation creates a favorable socio-economic dynamics stimulating capital flows for the intensification of work processes generated by human resources.

The money-goods economy is a great human achievement under condition that the abstract triad: capitallabor-money is completely recognized and respected. Then human capital becomes a source of labor and increasing value; that is to say, for creating well-being. Since human capital develops in a family unit, that's where the economics starts. Therefore, the family sector is an essential part of the economy and has serious responsibilities, comparable to that assigned to other sectors. Nonetheless, a correct valuation of human capital and an attention to fairness of compensation is the responsibility of country authorities.

\section{References}

[1] Atkins, P. (2007) Four Laws that Drive the Universe, Oxford University Press, New York.

[2] Kurek, B. and Dobija, M. (2013) Scientific Provenance of Accounting. International Journal of Accounting and Economics Studies, 1. http://dx.doi.org/10.14419/ijaes.v1i2.1054

[3] Dobija, M. (2007) Abstract Nature of Capital and Money, In: CornwallL. M., Ed., New Developments in Banking and Finance, Nova Science Publishers, Inc., New York, 89-114.

[4] Dobija, M. and Sliwa, M. (2001) Money as an Intellectual Venture, In: Kwiatkowski, S. and Stowe, Ch., Eds., Intellectual Product and Intellectual Capital, Wydawnictwo ALK im, Leona Koźmińskiego, Warsaw, 131-185

[5] Schmandt-Besserat, D. (2007) How Did Writing Arise (Jak powstało pismo). Wydawnictwo AGADE, Warsaw.

[6] Mattessich, R. (2000) The Beginning of Accounting and Accounting Thought. Accounting Practice in the Middle East (8000 B.C. to 2000 B.C.), Routledge, New York and London.

[7] Dobija, M. and Jędrzejczyk, M. (2011) Sketchesofthe History of Accounting (Szkice z historii rachunkowości). Polskie Towarzystwo Ekonomiczne, Kraków.

[8] Struve, W. (1969) Some New Data on the Organization of Labor and on Social Structure in Sumer During the Reign of the III rd Dynasty of Ur. In: Diakonoff, I.M., Ed., Ancient Mesopotamia. Socio-Economic History, Nauka, Moskwa, 127-172.

[9] Tyumenev, A. (1969) The Working Personnel on the Estate of the Temple of Ba-U in Lagasz during the Period of Lugalanda and Urukagina. In: Diakonoff, I.M., Ancient Mesopotamia. Socio-Economic History, Nauka, Moskwa, 173203.

[10] Roux, G. (1985) La Mesopotamie (Mezopotamia) Wydawnictwo Akademickie DIALOG, Warsaw.

[11] Polanyi, K., Arensberg, K. and Pearson, H. (1957) Trade and Market in the Early Empires. The Free Press, New York.

[12] Guyton, G.P. (1999) A Brief History of Workers’ Compensation. Iowa Orthopedic Journal, 19, 106-110.

[13] Smith, A. (1776) An Inquiry into the Nature and Causes of the Wealth of Nations. http://www.econlib.org/library/Smith/smWN2.html.

[14] Lebovitz, M.A. (2003) Beyond Capital. Marx’s Political Economy of the Working Class. Palgrave Macmillan, New York. http://dx.doi.org/10.1057/9781403943729

[15] Ijiri, Y. (1999) The Cost Principle and the Labor Theory of Value in Relation to the Role of Accounting Theories and Their Depth. In: Sunder, S. and Yamaji, H., Eds., The Japanese Style of Business Accounting, Quorum Books, Westport.

[16] Bryer, R.A. (1994) Why Marx’s Labor Theory Is Superior to Marginalist Theory of Value: The Case from Modern Financial Reporting. Critical Perspective on Accounting, 5, 313-340. http://dx.doi.org/10.1006/cpac.1994.1020

[17] Barrow, J.D. (2003) From Alpha to Omega, the Constant of Nature. Vintage Books, London.

[18] Pikulska-Robaszkiewicz, A. (1999) Usuryin the State and Law of the Republican Rome (Lichwa w państwie i prawie republikańskiego Rzymu). Wydawnictwo Uniwersytetu Łódzkiego, Łódź.

[19] Damodaran, Aswath, Equity Risk Premiums (ERP): Determinants, Estimation and Implications-The 2013 Edition (March 23, 2013). Available at SSRN: http://ssrn.com/abstract=2238064 or http://dx.doi.org/10.2139/ssrn.2238064

[20] Ibbotson, R.G. and Goetzmann, W.N. (2005) History and the Equity Risk Premium. Yale ICF Working Paper No. 0504. http://ssrn.com/abstract=702341

[21] Kurek, B. (2012) An Estimation of the Capital Growth Rate in Business Activities. Modern Economy, 3, 364-372. http://dx.doi.org/10.4236/me.2012.34047 
[22] Dobija, M. (2011) Labor Productivity vs. Minimum Wage Level. Modern Economy, 2, 780-787. http://dx.doi.org/10.4236/me.2011.25086

[23] Kozioł, W. (2010) Fixed Wage Based on Human Capital (Kształtowanie płac stałych na podstawie kapitału ludzkiego). In: Dobija, M., Ed., Teoria pomiaru kapitatu i zysku, Wydawnictwo Uniwersytetu Ekonomicznego w Krakowie, Kraków, 73-100.

[24] Renkas, J. (2012) The Empirical Test of the Model of Human Capital and Minimum Wages (Empiryczny Test modelu kapitału ludzkiego i minimalnych wynagrodzeń). Nierówności społeczne a wzrost gospodarczy, 24, 345-356.

[25] Wright, R. (2000) Nonzero. Logicof Human Destiny (Logika ludzkiego przeznaczenia). Prószyński i S-ka, Warszawa.

[26] Atkins, P. (2005) Galileo’s Finger-The Ten Great Ideas of Science (Palec Galileusza. Dziesięć wielkich idei nauki). Dom Wydawniczy Rebis, Poznań.

[27] Dobija, M. (1998) How to Place Human Resources into the Balance Sheet? Journal of Human Resource Costing \& Accounting, 3, 83-92. http://dx.doi.org/10.1108/eb029044

[28] Robinson, J. (1953-1954) The Production Function and the Theory of Capital. Review of Economic Studies, 21, 77-89. http://dx.doi.org/10.2307/2296002

[29] Dobija, M. and Jędrzejczyk, M. (2013) Productin Function in the Cost Accounting Approach and Managerial Applications. Zeszyty Teoretyczne Rachunkowości, 72, 49-62.

[30] Jędrzejczyk, M. (2012) Labor Productivity Parity vs. Trend of Exchange Rate. Modern Economy, 3, 780-785. http://dx.doi.org/10.4236/me.2012.36099

[31] Dobija, M. (2011) Abstract Nature of Money and the Modern Equation of Exchange. Modern Economy, 2, $142-152$. http://dx.doi.org/10.4236/me.2011.22019

[32] Forbes (2013) Fed ogranicza dodruk pieniądza. http://www.forbes.pl/

[33] Bossone, B., Fazi, T. and Wood, R. (2014) Helicopter Money: The Best Policy to Address High Public Debt and Deflation. VOX CEPR's Policy Portal. http://www.voxeu.org/article/helicopter-money-today-s-best-policy-option

[34] Włodarczyk, R. (2014) Currency Wars in the Present World Economy. Miscellanea Oeconomicae, 81, $299-312$.

[35] Dobija, M. (2014) The Global Currency Area a Way to Constructively End the Era of Reserve Currency. Modern Economy, 5, 289-302. http://dx.doi.org/10.4236/me.2014.54029

[36] Dobija, M. (2014) Formation of the Integrative Currency Area. SOP Transactions on Economic Research, 1, 1-9. 